\title{
Individual Character: A Perspective
}

\author{
H.H.D.N.P.Opatha
}

\begin{abstract}
Seemingly Western literature and Eastern literature of Human Resource Management (HRM) reveal a gap in the theoretical knowledge as well as the empirical knowledge in respect of Individual Character (IC) and human resource development through character building. Studies will have to be carried out in order to develop a pragmatic framework of describing character and explaining its dynamics; a logical model of explaining the relationship between character and HRM; and a pragmatic framework of character development at the micro (organizational) level. Though there are several research questions which need to be answered systematically and scientifically, the objective of this research paper was to explore what IC means, whether IC differs from the concept of so called personality and why IC is important, specially in current Sri Lankan context. Ostensibly, the approach of the paper was reflective and descriptive. IC was defined as the aggregate of all of the relatively persistent moral qualities a person has that combines to form his/her real nature. It is the degree to which the person possesses the virtues and do not possess the vices. Virtues are to be nurtured within the individual while vices are to be removed from the individual for the purpose of developing IC. It was asserted that IC was not the so called personality and it differed significantly from personality in several ways. It was substantiated by literature that IC is of utmost importance for individual development, organizational development and nation development as well.
\end{abstract}

Key words: Individual Character, Morality, Personality, Values, Vices, Virtues

\section{Introduction}

It is theoretically and empirically evident that success of any organisation heavily depends of quality of its human resources and quality of human resources heavily depends on good Human Resource Management (HRM). It has been observed that despites so called conceptual, human and technical competencies of employees (specially managers) it seems that there is something missing from them in order to maintain, improve and develop performance aspects of an organisation such as effectiveness, efficiency, productivity, profit, quality, safety, growth, attendance, retention, satisfaction, motivation, innovation and adaptability. It is argued that the missing is Individual Character (IC) that has been generally agreed as one of the greatest motive powers in the world. A gross observation of various successful and unsuccessful managerial incidents gives a serious enthusiasm to research into the phenomenon of IC that is relatively a new concept as far as HRM literature is concerned. It seems that Western HRM literature and Eastern HRM literature reveal a gap in the theoretical knowledge and the empirical knowledge as well with regard to individual character and human resource development 
through character building. Studies need to be carried out by aiming at developing a pragmatic framework of describing character and explaining its dynamics; developing a logical model of explaining the relationship between character and HRM; and building a pragmatic framework of character development at the micro (organizational) level. Some of the research questions which need to be answered systematically and scientifically in order to achieve the above aims are:

1. What is IC? Is it a unique concept? Does it differ from so called personality?

2. If it differs, how and why?

3. Why is IC important?

4. Is character an explanatory variable of behaviour of successful people who have immensely contributed to human development and organizational development?

5. Does character relate to one's performance significantly?

6. What is the relationship between IC and HRM? What are the linkages between IC and HRM functions?

7. Is character building the common denominator that will help the organization reach all of its goals?

8. How to measure character?

9. How to build character in general and with special reference to work (after employing a person) under human resource development function of HRM?

10. What propositions can be formulated for future studies especially empirical studies, which involve hypotheses testing?

In search of systematic and scientific answers, nature of studies will have to be exploratory initially and later descriptive and explanatory. A serious level of literature review with regard to writings of religions, philosophy, ethics and education will have to be performed though it may not necessarily be exhaustive. Ex post facto research design will also be more useful. Nonetheless, this paper is a preliminary attempt to find systematically acceptable and logical answers for three of the above mentioned research questions. The objective of the current paper as an initiative is to explore what IC means, whether IC differs from the concept of so called personality and why IC is important, specially in current Sri Lankan context. Consequently the paper seeks to provide a general comprehension of individual character with a comparison between IC and personality. Ostensibly, the approach of the paper is reflective and descriptive.

\section{Toward A Definition of Individual Character}

The meaning of character is not concrete as the concept is abstract. Word itself is ambiguous as it has many meanings. From the focus of this paper it is about a person's character. A universally accepted definition is unavailable. The character of a person, group of people, place, etc consists of all the qualities they have that combine to form their personality or atmosphere (Collins Birmingham University English Language Dictionary, 1987). Accordingly a person's character is the totality of the qualities he/she has that forms his/her personality. The Oxford Paperback Dictionary (1979) defines character as a person's moral nature. The Oxford Paperback Dictionary defines moral as concerned with the goodness and badness of human character or with the principles of what is right and wrong in conduct and also the same defines it as being virtuous. Moral 
means concerned with the question of whether people's behaviour is right, proper, or acceptable according to the Collins Birmingham University English Language Dictionary. Viewing from the above character is about morality.

Samuel in the opening of his book, 'character' (as in Macmillan and Macmillan, www.cepnz.co.nz/faq.html) describes that character is one of the greatest motive powers in the world. In its noblest embodiments, it exemplifies human nature in its highest forms, for it exhibits man at his best. In fact what Samuel describes is character of a person that is positive connotation. Wynne and Walberg (1984, as in Huitt, 2004) provide a normative view of character as "engaging in morally relevant conduct or words, or refraining certain conduct or words". Accordingly character is about a person's engagement in right behaviour and use of right words and non-engagement in wrong behaviour and use of wrong words. Pritchard (1988, as in Huitt, 2004) defines character normatively as "a complex set of relatively persistent qualities of the individual person, and generally has a positive connotation when used in discussions of moral education. This normative definition implies that character of a person is a set of relatively constant qualities involving many different things that are connected to each other.

Macmillan and Macmillan, www.cepnz.co.nz/faq.html define that character is that which defines who a person really is - how they think and act and their motive behind their actions. Accordingly character is the actual nature of the person. It involves real thinking, acting and actual purpose of actions of a person. It has cognitive, affective and behavioural components. The International Association of Character Cities defines character in its 2006 Calendar as "the inward desire to do what is right, whatever the cost". This definition stresses that character of a person is a strong inner feeling to do what is right irrespective of whatever the cost of doing is. It is possible to argue that there is a strong relationship between the desire and the behaviour. It is more likely that a person who has an inward desire to do what is right at whatever cost behaves rightfully in the reality.

It is possible to note that character is a word that involves morality or immorality having the following features:

(a) It is personal. It is possessed by a person.

(b) It is the aggregate of special qualities.

(c) It is about morality.

(d) It is about a person's engagement in right behaviour and use of right words and nonengagement in wrong behaviour and use of wrong words.

(e) It has a complex set of relatively persistent qualities.

(f) It is about real nature of a person - how he/she thinks and acts and his/her motive behind his/her actions.

(g) It is the inward desire of a person to do what is right at any cost.

Thus, character of a person is defined as the aggregate of all of the relatively persistent moral qualities he/she has that combines to form his/her real nature. Character of a person consists of virtues and may consist of values as well. Following figure includes the above characteristics derived from the review of the definitions. 


\section{Figure: 1 Characteristics of Individual Character}

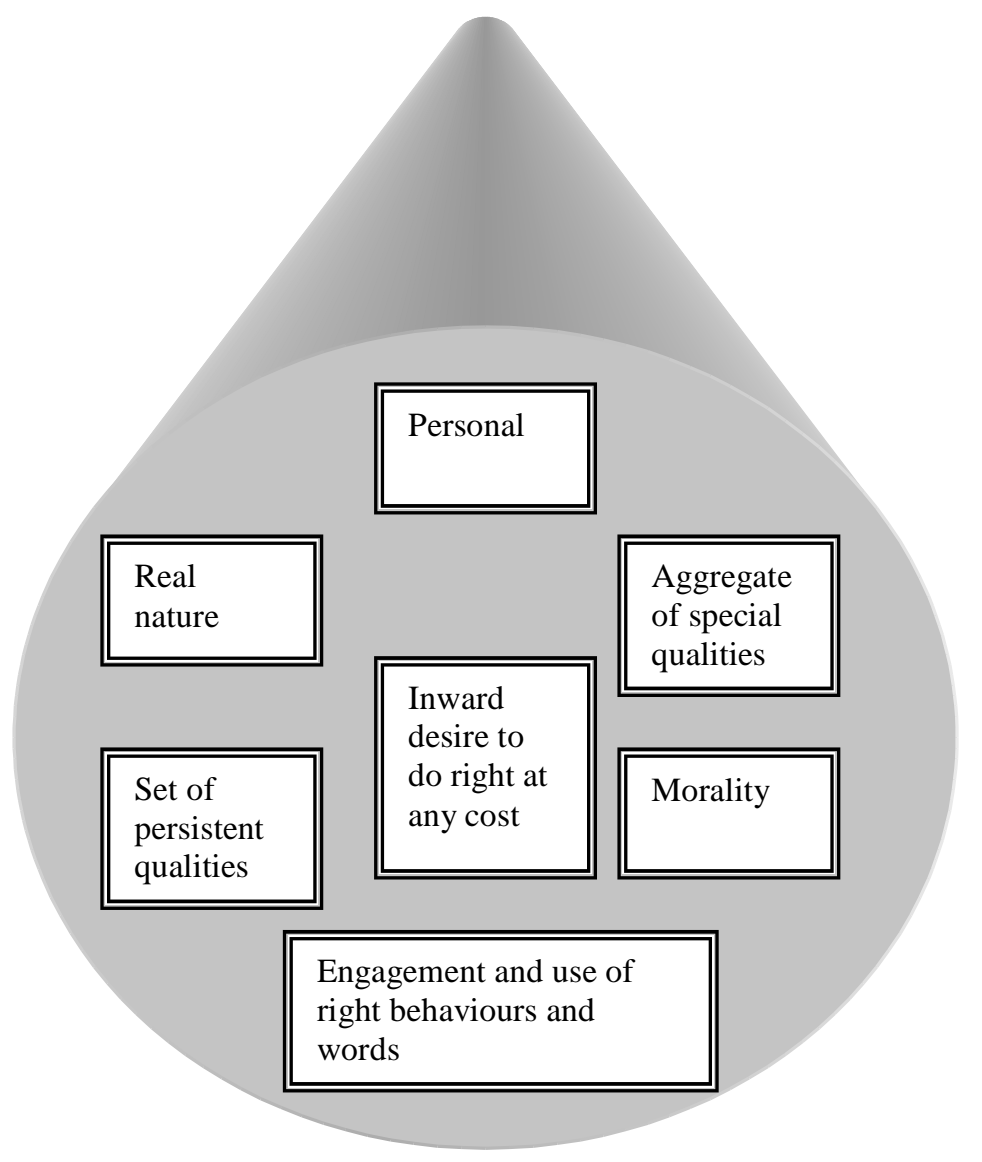

\section{Virtues}

The Collins Birmingham University English Language Dictionary defines a virtue as thinking and doing what is right and avoiding what is wrong or a good quality that a religion or society teaches one to respect. According to the Oxford Paperback Dictionary, it is moral excellence, goodness or a good quality. Macmillan and Macmillan, who are husband and wife, developed Character Education Programme of New Zealand (www.cepnz.co.nz/faq.html) differentiate between Values and Virtues. They write:

"Values are any ideals, goals or standards upon which actions or beliefs are based. But a person may value poetry, but never read any. A person may value honesty in others but remain dishonest themselves. They can be sometimes pointless or selfish and at times can hurt other people when they value the rights of one group over another. It is only when a person's values are built upon the foundation of virtues that true, strong and good character can be developed. Virtues are qualities of moral goodness or excellence and they are beyond the limits of religion, culture, nationality or sex-they are universally accepted principles. They include responsibility, honesty, reliability, respect for others, compassion and empathy etc." 
Values are what people appreciate. Of course virtues are also appreciated and are to be appreciated by people. However, some values may not be appreciated by some people. For instance, respecting to the adults is valued by traditional Sri Lankan people. It may not be valued by another nation's people. Playing cricket may be a value of one group of people but it may not be a value of another group of people. Refraining from killing any creature is a serious value of Buddhism and it may not be a value of another religion. Thus, values tend to be different from religion to religion, culture to culture, one nationality to another, one race to another, and one group to another group of the same nationality. Virtues do not differ in terms of nationality, religion, race, cast, sex, and other classifications in the society. Hence they are absolutes but not relatives like values. In fact, character is what a person is really. It is to what extent a person possesses virtues. They include patience, responsibility, honesty, respect for others, determination, punctuality, courage, compassion, empathy etc. Virtues are the qualities to be nurtured within a person until they are upheld as a matter of habit.

Virtues can generally be divided into two categories such as personal virtues and social virtues. Personal virtues are more individual-related, more for the person's development, qualities towards self and individually desirable qualities while social qualities are more group-related, more for others' development, qualities towards others, and socially desirable qualities. Personal virtues bring happiness within the person. Social virtues bring happiness within the persons with whom one associates or interacts. Personal virtues can be operated in the individual context while social virtues can be operated in the social context. Some examples of personal virtues are patience, courage, selfdiscipline, punctuality, resourcefulness, tolerance, endurance, persistence, diligence, loyalty, sensitivity and responsibility. Hospitality, benevolence, courteousness, compassionateness, trustworthiness, generosity, respect/honour and gentleness are some examples of social virtues. Both types of virtues are to be possessed by a person so as to become a person of high degree of character.

\section{Vices}

The Collins Birmingham University English Language Dictionary defines a vice as a serious moral fault in someone's character. Also the Dictionary defines it as a criminal behaviour that is regarded as immoral. According to the Oxford Paperback Dictionary, it is an evil or grossly immoral conduct, great wickedness or a particular form of a fault or bad habit or a criminal and immoral practice. Vices are negative qualities which need to be totally eradicated or alleviated within a person. In fact, character is to what extend a person possesses vices. Ideally the extent to which vices are possessed by a particular person should be zero or minimum to have the highest level of good character. They include jealousy, greed, anger, stinginess, doubt, deception, corruption, retaliation etc. Vices are the mal-qualities to be removed from a person until they become totally eradicated.

While virtues are to be nurtured vices are to be removed for the purpose of developing a good character. Following figure 2 shows this prescription diagrammatically. Exhibit 1 sets out a list of specific virtues and vices. 
Figure: 2 Virtues and Vices for Development of Good Character

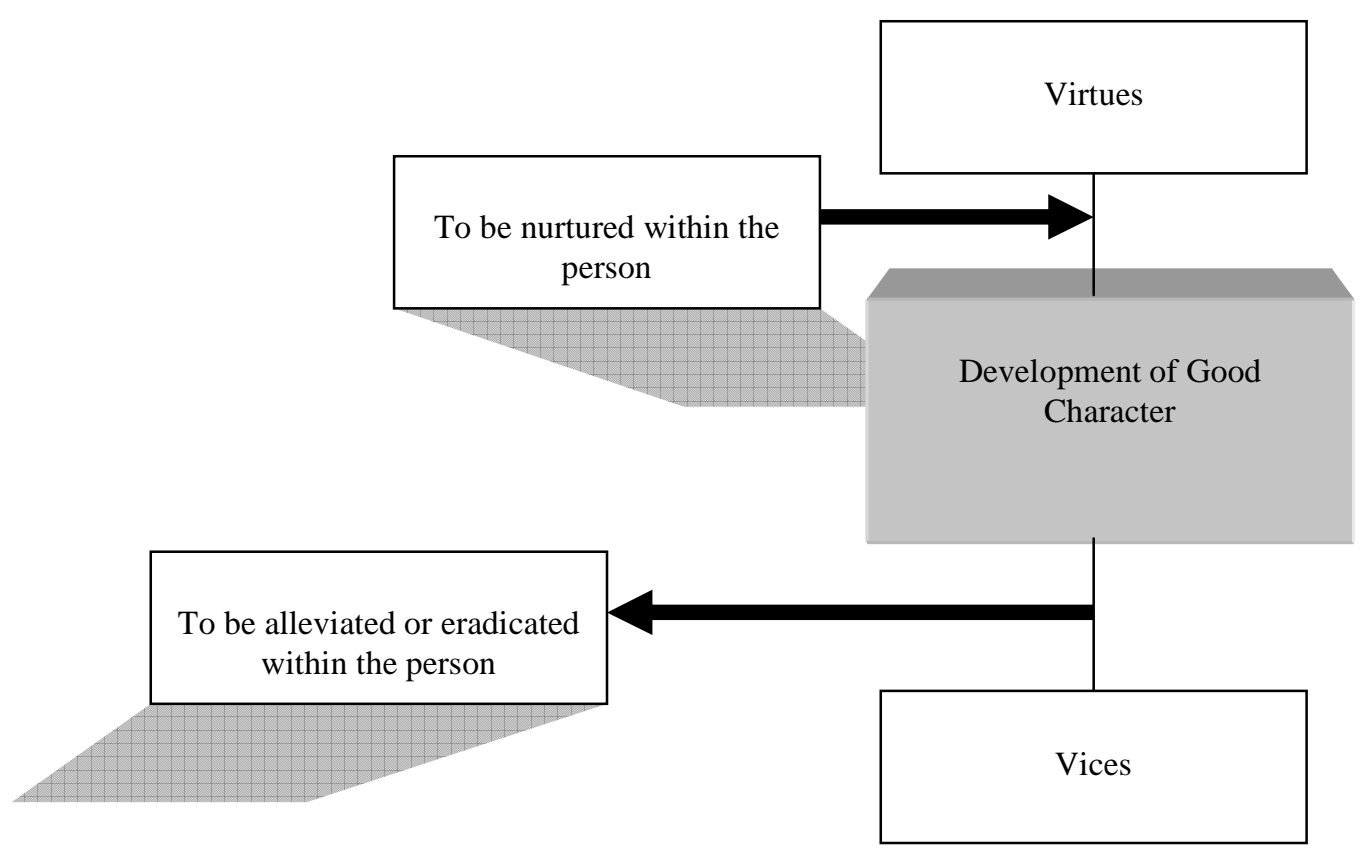

Exhibit: 1 Specific Virtues and Vices

\begin{tabular}{||l|l||}
\hline Virtues & Vices \\
\hline Benevolence & Anger \\
Caring & Apathy \\
Compassion & Blind Imitation \\
Courage & Corruption \\
Courteousness & Deception \\
Decisiveness & Discouragement \\
Dependability & Doubt \\
Determination & Greed \\
Diligence & Harshness \\
Enthusiasm & Hostility \\
Generosity & Idleness \\
Gratitude & Jealousy \\
Honesty & Lust \\
Hospitality & Prejudice \\
Humility & Pride \\
Initiative & Reprobation \\
Justice & Retaliation \\
Love & Self-indiscipline \\
Loyalty & Selfishness \\
Obedience & Stinginess \\
Patience & Tardiness \\
Perseverance & Ungratefulness \\
\hline
\end{tabular}




\begin{tabular}{|l||l||}
\hline Punctuality & Wastefulness \\
Resourcefulness & \\
Respect & \\
Responsibility & \\
Sacrifice & \\
Self-discipline & \\
Sensitivity & \\
Tolerance & \\
Unity & \\
\hline
\end{tabular}

\section{Personality}

Though the term 'Personality' is also an abstract concept it is a well established concept in the literature of HRM and Organizational Behaviour as far as the field of Organizational Management is concerned. Of course the term is a major concept in the field of Psychology. However, a universally accepted definition of the term is unavailable. Glueck (1979, p. 39) defines "personality is the characteristic way a person thinks and behaves in adjusting to his or her environment. It includes the person's traits, values, motives, genetic blueprint, attitudes, emotional reactivity, abilities, self-image, and intelligence. It also includes the person's visible behaviour patterns." Accordingly, personality involves a set of mental and physical qualities of a person. It is how a person thinks and behaves when that person adjusts to his/her environment. Psychologist Zimbardo (1979, p. 292) defines personality as "the sum of the unique psychological qualities of an individual that influence a variety of characteristic behaviour patterns (both overt and covert) in relatively consistent ways across different situations and over time." This definition stresses concept of uniqueness, characteristic responses and situational consistency. There are unique characteristics that distinguish individuals from one another. There is some stability to personality from one time to another time. Relatively personality of one person does not change from one situation to another. Personality is a stable set of characteristics and tendencies that determine our thoughts, feelings, and actions in combination with the social and biological pressures of the moment (Maddi, 1980, as in Umstot, 1984, p.29). As per Maddi and Umstot, a person's personality is a steady set of characteristics and tendencies determining that person's thoughts, feelings and actions. The moment or situation is important to understand the personality. A person's personality may get different depending upon the existing social and biological pressures of the situation. For instance, you behave in a particular way when you are listening to a lecture in the class but you behave in a different way when you are in a room of one of your friends. Organizational situations create pressures on personality (Umstot, 1984). For instance, a normally congenial and friendly person may become quite hostile due to a bad behaviour of a subordinate who had not performed an essential duty.

Dunham (1984, p.221) writes "Personality distinguishes you from other people and defines your general nature. Your overall personality is composed of a collection of psychological characteristics or traits which determines your personal preferences and individual style of behaviour." This writing suggests that different people have different personalities and a person's personality comprises of a set of psychological 
characteristics which is the determinant of his/her personal preferences and his/her individual behaviour style. According to Chandan (1999, p.149), personality is a set of relatively stable characteristics or dimensions of people that account for consistency in behaviour in various situations. Further he (p.144) writes "If a person's entire personality could change suddenly, then we would not be able to predict his personality traits. For example, if we believe that someone has a warm and friendly personality and the person is sometimes warm and friendly and at other times he is cold and hostile then we cannot conclude that his personality is warm and friendly. Accordingly, when assessing a person's personality we need to look for characteristics that are relatively stable or that change only very slowly over a long period of time."

Writings of Chandan show personality as a set of characteristics which are relatively consistent and do not change within a short time. Parkinson (2002) defines personality as the characteristic way in which someone responds to situations, or their preferred way of behaving towards particular circumstances and other people. According to him, personality stems from person as an individual; it predicts his/her behaviour over a range of situations; it does not alter dramatically over time; and it distinguishes one person in meaningful ways from other people.

There may be various types of personality with regard to employees who work for a particular organization. Employees become different because their personalities are different. Dunham (1984, p.236) writes about five personality characteristics namely locus of control (the degree to which a person believes his/her actions influence outcomes experienced); authoritarianism (the degree to which a person believes there should be clearly defined and followed status and power levels in organizations); dogmatism (the degree to which a person is closed-minded, with a very rigid belief system); Machiavellianism (the degree to which a person focuses on obtaining and using power to further his/her own ends, regardless of the impact on others; and type A/B trait (the degree to which a person chooses to work aggressively under pressure with an impatient and competitive approach to others). Chandan (1999) writes about authoritarianism, bureaucratic personality, Machiavellianism, problem solving style, locus of control, and introvert \& extrovert personalities as personality dimensions. Implication of these writings is that there are different types of personality characteristics individuals in an organization or a society possess.

\section{A Comparison}

It is argued that character differs from personality. Different people can have different personalities. Locus of control is a personality characteristic and one may have an internal locus of control (believing that one controls one's own destiny) while another may have an external locus of control (believing that other factors such as luck, other people and organizations are primary determinants of his/her destiny). It is not possible to conclude that the first person (with internal locus of control) is right and the latter is wrong. Also it is not essential to change one's locus of control. We should not try to develop one type of personality within all employees or people. Also trying so is pointless as it is not attainable. It is possible to define an ideal character and an endeavour can be made to develop that ideal character within every person. Trying so is meaningful as it is attainable (and of curse it is to be attained for a better society/organization). One 
virtue is honesty. It is possible to try to make every person to become honest. Also it is essential to do so for a better society/organization. In fact different people are likely at different levels of character development (one can be found anywhere on a continuum of character- very good, good, moderate, bad or very bad). However, it is expected that every person should reach a high level of character development, i.e., every one should be a person of very good character.

In terms of personality we can be different and being so is acceptable. In terms of character we should not be different and being different is unacceptable. Good character is something that is definite and will not change if circumstances change. Hence it is absolute. Personality is something that is vague and may change if circumstances change. For instance, an authoritarian person will reduce his/her authoritarianism in order to lead non-authoritarian subordinates (if he/she wants to be a successful leader). Personality of a person cannot be judged to be good or bad in itself, but needs to be considered and judged in the context of other factors. Hence it is relative not absolute. There is no universally accepted personality type for betterment of society though there is a universally accepted nature of character. Though there are different types of personality there are no different types of character-ideally there is one type, i.e. good character. For a better organization persons of different personalities can be expected but persons of different characters cannot be expected. Persons of same character (that is good character) are expected and accepted. Personality characteristics are descriptions of what different people have or do. Character qualities are prescriptions for what everyone should do. Virtues become morally and universally imposed normative standards of person's thinking, feeling and behaving. Differences between personality and individual character are set out in table 1 .

Table: 1 Differences between Personality and Individual Character

\begin{tabular}{|l|l||}
\hline Personality & Individual Character \\
\hline \hline $\begin{array}{l}\text { To attempt to develop one type of } \\
\text { personality within all employees or people } \\
\text { is not necessary. Also it is likely } \\
\text { impossible. }\end{array}$ & $\begin{array}{l}\text { To attempt to develop good character } \\
\text { within all employees or people is } \\
\text { necessary. Also it is likely possible. }\end{array}$ \\
\hline \hline It is relative. & It is absolute. \\
\hline $\begin{array}{l}\text { There is no universally accepted nature of } \\
\text { personality for betterment of society. }\end{array}$ & $\begin{array}{l}\text { There is a universally accepted nature of } \\
\text { character for betterment of society. }\end{array}$ \\
\hline \hline There are different types of personality. & $\begin{array}{l}\text { There are no different types of character. } \\
\text { Ideally there is one type, i.e. good } \\
\text { character. }\end{array}$ \\
\hline \hline $\begin{array}{l}\text { Generally personality characteristics are } \\
\text { descriptions of what different people have } \\
\text { or do. }\end{array}$ & $\begin{array}{l}\text { Generally character qualities are } \\
\text { prescriptions for what everyone should do. }\end{array}$ \\
\hline \hline
\end{tabular}




\section{Importance of Good Character}

A person with a good character is able to lead a good life; to perform at any situation in an acceptable way; to contribute to his/her own development; to help others to develop; and contribute significantly to develop his/her family, his/her village/town and finally his/her country. Having good character is as indispensable as having appropriate competence in a chosen field of study for any person. In fact good character will contribute to secure the required competence in a chosen field of study. A person who wants to become a successful professional in a certain field (may be in HRM or may be in Accounting and Finance or any other field) should have right technical competence (knowledge and skills acquired through education, experience and training), right human relation competence, right conceptual competence, right attitudes (job satisfaction, organizational citizenship behaviour, job involvement, organizational commitment), positive thinking, and of course what is called Character. Possession of right character will lead to one to acquire, build, maintain and improve all types of competencies required to be successful on a job or profession, right attitudes and positive thinking.

Do you want to be the best person in a certain field of Sri Lanka compared with your peers or even with non-peers/all? Can you be the best? If you think that you are not in a position of becoming the best in the field (due to some reasons which may be uncontrollable), then

Do you want to be one of the best persons in a certain field of Sri Lanka? Can you be one of the best? If you think that you are not in a position of becoming one of the best in the field (due to some reasons which may be uncontrollable), then

Do you want to be an excellent person/ a person of success in a certain field of Sri Lanka? Can you be excellent or successful?

In order to be the best or one of the best or excellent, you must possess a GOOD CHARACTER. A person of good character not only develops himself/herself but also develops others to the possible extent. Without it you may be a person who is unsuccessful, ineffective, inefficient, unimportant, and not worthy. If you possess a bad character you will be a curse to the society. You cause a great deal of harm to others. Even after your death, the society will curse you. Perhaps even your close relatives would do so.

The life for one day of one who is virtuous and contemplative is better than if one were to live for a hundred years, immortal and distracted.

(The Incomparable Buddha, Dhammapada as in Adikaram, 2004)

True foundation for a person to live peacefully comes from character development.

If there is righteousness in the heart there will be beauty in character.

If there is beauty in character there will be harmony in the home.

If there is harmony in the home there will be order in the nation.

If there is order in the nation there will be peace in the world.

(A Chinese proverb)

(Source: International Association of Character Cities) 
Character development will have a long-term effect on improving social and intercultural harmony. When you are alone, are you happy genuinely? If you are so, definitely you must possess a good character. Given enough character, man becomes a true man; and a true man alone can solve his own problems and help solve those of others (Budhananda, 2005). Since person is imperfect by nature, he/she has to make an effort to develop virtues (Dhammananda, 1998). As virtues are valid and unchanging universally accepted qualities one must possess these in order to be universally accepted, at least to be accepted by his/her colleagues and superiors. One's destiny depends on character. Good thoughts lead to good words and actions, when these actions are continuously made, they become good habits which result in the creation of good character that finally results in good destiny (see exhibit 2).

\section{Exhibit: 2 Relationships between Dreams and Destiny}

Keep Watch (pay attention to what is happening so that action can be taken at right moment)

Watch your dreams;

They become thoughts.

Watch your thoughts;

They become words.

Watch your words;

They become actions.

Watch your actions;

They become habits.

Watch your habits;

They become the character.

Watch your character;

They become your destiny.

Source: Pravsworld.com (as in Silva, 2006)

There can be seen many evil/wicked consequences in the absence of good character in the society. Poverty brutalizes and affluence barbarizes man if he does not have enough character qualities (Budhananda, 2005). Lack of good character in our society causes a great deal of harm to people and, the society will have to be regarded as morally bad. Exhibit 3 shows consequences of character.

Reverent Seelawansa (2001, p.7) notes: "Among strengths, character strength is principal. Though one has physical and knowledge strengths, if there is no character strength he is an enemy to himself. There will be a catastrophe from him to himself and to the country...character strength makes you a gentleman." Swami Budhananda (2005, p.8) prefaces: "Character is the light which shines when the sun is down, and all other lights are out. Character is that power, with which we can win victory even when losing 
battles. Character is the awakened divine in man, before whom all heads bend, except those of the insane. Character is that afflatus which shines even in poverty. Character is that impregnable foundation on which stand all indestructible institutions of life. Robbers can break open and rob everything in the world, but not character. When we have lost everything but not character, we have not really lost anything. ... Character-transmission is the essential mission of education. ...Characterlessness is that destitution which can not be worsened."

Exhibit: 3 Consequences of Character

\begin{tabular}{|l|l|}
\hline $\begin{array}{l}\text { Consequences due to presence of bad } \\
\text { character in the society }\end{array}$ & $\begin{array}{l}\text { Consequences due to presence of good } \\
\text { character in the society }\end{array}$ \\
\hline Many Illegitimate Births & Many Legitimate Births \\
Many Suicides & Many Natural Deaths \\
Many Homicides & Many Healings \\
More Violence & Much Peace \\
Many Crimes & Less or No Crimes \\
Many Prison Sentences & Less or No Prison Sentences \\
Unethical Decision Making & Ethical Decision Making \\
Low or Declining Industrial Productivity & High or Increasing Industrial Productivity \\
Low or No Time Efficiency & High Time Efficiency \\
Unsafe Places & Safe Places \\
Industrial Unrest & Industrial Peace \\
Corruption and Nepotism & Fairness and Lack of Favouritism \\
Secularity & Religiousness \\
Hedonism & Transcendence and Spirituality \\
Ruination & Development \\
Unbalanced Life & Balanced Life \\
Ill Will & Good Will \\
Sickness & Healthiness \\
Poverty & Affluence/Prosperity \\
Non-simultaneous Advancement of All & Simultaneous Advancement of All \\
\hline
\end{tabular}

The state of having no character has no possibility of getting more unacceptable or severe. Thus, character is a serious total quality one must possess in order to develop $\mathrm{him} / \mathrm{her}$, others and the society at large. At the individual level, micro level (organization level), and macro level as well there is a constant need to develop people's individual character through a proper character development programme. Character development is a deliberate effort to develop virtues within a person that are good for the individual, the organization where the individual works and the society where he/she lives as well. Also it is a formal deliberate attempt to eradicate or alleviate vices from the person as much as possible. Any programme for developing individual character should meet the classical ethical tests of reversibility (Would you want to be treated this way?) and universalizability (Would you want all persons to act this way in a similar situation?)." according to Lickona (as in thinking media, 2003). Ideally a person who treats others 
morally expects to be treated by others morally. Also a person of good character wants all other persons to act morally in a similar situation.

\section{Conclusion}

Being the aggregate of all of the universally persistent moral qualities a person has combining to form that person's real nature, the character has become an essential phenomenon in the human resource development context. Character is the extent to which the person possesses the virtues and do not possess the vices. Character is not the so called personality and several significant differences exist between individual character and personality. A person of good character will be an asset and a benediction to the family, village/town, organisation, country and the world as well. In order to develop a person of good character, a development programme is needed and it is a deliberate and planned endeavour to develop virtues (while minimising vices to possible minimum extent) that are essentially good for the individual, organisation and the society as well.

\section{References}

Adikaram, E.W. (2004), DHAMMAPADA, Colombo: Gunesena.

Budhananda, S. (2005), How to Build Character, Kolkata: Advaita Ashrama.

Chanaseeha, H. (2002), Hadagahena Charithaya (Building Character), Colombo: Rathna Books Publishers.

Chandan, J.S. (1999), Organizational Behaviour, New Delhi, Vikas Publishing House.

Character Training Institute (1994), Seven Leadership Perspectives, Pocket Guide.

Collins Birmingham University International Language Database (Cobuild) English Language Dictionary (1987), London: Collins.

Dhammananda, K. Sri. (1996), Why Worry? How to live without fear and worry, Kuala Lumpur: Buddhist Missionary Society.

Dunham, R.D. (1984), Organizational Behavior, Homewood, Illinois: Richard D. Irwin.

Elkind, D.H. and Sweet, F. (2004), You Are A Character Educator, Today's School, Sept/Oct as in goodcharacter.com

Glueck, W.F. (1979), Foundations of Personnel, Texas: Business Publications Inc.

Hitt, M.A., Middlemist, R.D. and Mathis, R.L. (1979), Effective Management, New York: West Publishing Co.

Huitt, W. (2004), "Moral and Character development", Educational Psychology Interactive, Valdosta, GA: Valdosta State University.

International Association of Character Cities, Character Precepts training Institute, Character First!, 2006 Calendar, cpti@lankabellnet.com.

Macmillan and Macmillan, www.cepnz.co.nz/faq.html

Parkinson, M. (2002), How to master personality questionnaires, London: Kogan Page.

Seelawansa, T. (2001), Dhawasa (Day), Colombo: Gunesena

Silva, Prialal. (2006), Character: True Foundation of Human Resources, an unpublished

MBA Thesis, Irish International University.

The Oxford Paperback Dictionary (1979), Oxford: Oxford University Press.

Thinking Media, 2003 
Sri Lankan Journal of Human Resource Management

Umstot, D. D. (1984), Understanding Organizational Behaviour, New York: West Publishing Company.

Virtues Project International (2001), What are the virtues?

Zimbardo, P.G. (1979), Essentials of Psychology and Life, $10^{\text {th }}$ Edi, Clenview, Illinois: Scott, Foresman and Company. 